\title{
Possible Synergic Effect of Angiotensin-I Converting Enzyme Gene Insertion/Deletion Polymorphism and Angiotensin-II Type-1 Receptor 1166A/C Gene Polymorphism on Ischemic Heart Disease in Patients with Kawasaki Disease
}

\author{
RYUJI FUKAZAWA, TOMOYOSHI SONOBE, KUNIHIRO HAMAMOTO, KENJI HAMAOKA, \\ KOICHI SAKATA, TAKESHI ASANO, TAKEHIDE IMAI, MITSUHIRO KAMISAGO, \\ TAKASHI OHKUBO, YOHKO UCHIKOBA, EI IKEGAMI, MIKI WATANABE, AND \\ SHUNICHI OGAWA
}

Department of Pediatrics [R.F., T.A., T.I., M.K., T.O., Y.U., E.I., Y.K., M.W., S.O.], Nippon Medical School, 113-8603 Tokyo, Japan, Department of Pediatrics [T.S.], Japanese Red-Cross Medical Center, 150-0012 Tokyo, Japan, Department of Pediatrics [K. Hamamoto], School of Medicine, Fukuoka University, 814-0180 Fukuoka, Japan, and Division of Pediatrics [K.S., K. Hamaoka], Children's Research Hospital, Kyoto Prefectural University of Medicine, 602-0841 Kyoto, Japan

\begin{abstract}
$A C E \mathrm{I} / \mathrm{D}$ and $A T 1 R$ 1166A/C polymorphisms are considered to comprise individual risk factors for the development of coronary disease. We sought to demonstrate that the $A C E \mathrm{I} / \mathrm{D}$ and ATIR $1166 \mathrm{~A} / \mathrm{C}$ polymorphisms affect coronary artery stenosis in patients with Kawasaki disease (KD). We examined 147 healthy controls and 281 Japanese children with KD. The patients were further divided into group $\mathrm{N}(n=246$, no ischemia) and group I $(n=35$, severe coronary artery stenosis with myocardial ischemia), and we studied the genotype of $A C E \mathrm{I} / \mathrm{D}$ and $A T 1 R$ $1166 \mathrm{~A} / \mathrm{C}$ polymorphisms. We also examined ACE activity in patients with acute KD. We did not detect any prevalent genotypes of the $A C E$ and $A T 1 R$ polymorphisms between controls and $\mathrm{KD}$ patients. However, the prevalence of the $\mathrm{D}$ allele in the $A C E$ polymorphism and of the $\mathrm{C}$ allele in the $A T 1 R$ polymorphism tended to be higher in group I than in group $\mathrm{N}$ (odds ratios, 2.00 and 2.32, respectively). In addition, the presence of the $\mathrm{D}$ and/or $\mathrm{C}$ alleles significantly increased the relative risk of developing
\end{abstract}

\section{ABSTRACT}

myocardial ischemia (odds ratio, 2.71; $p=0.038$ ). During the convalescent phase of $\mathrm{KD}$, ACE activity was increased despite significant attenuation during the acute phase. These results suggested that the renin-angiotensin system is associated with the formation of severe coronary artery stenosis and myocardial ischemia. (Pediatr Res 56: 597-601, 2004)
Abbreviations
ACE, angiotensin converting enzyme
AgII, angiotensin II
AT1R, angiotensin II type 1 receptor
CA, coronary artery
CAD, coronary artery disease
IVIG, intravenous Ig therapy
KD, Kawasaki disease
RAS, renin-angiotensin system

$\mathrm{KD}$ is characterized by systemic vasculitis of mid-sized arteries, and coronary arteritis that sometimes results in cardiac events such as ischemia, myocardial infarction (MI), or sudden death. More than 6,000 children (58\% are male, and 55\% are under 2 y of age) in Japan develop KD annually. Despite Ig

Received September 30, 2003; accepted April 28, 2004

Correspondence: Ryuji Fukazawa, M.D., Nippon Medical School, Department of Pediatrics 1-1-5 Sendagi, Bunkyo-ku, Tokyo, Japan 113-8603; e-mail: oraora@nms.ac.jp

Supported by the Japan Society for the Promotion of Science (Grant-in-Aid for Scientific Research (C) 12670787), Tokyo, Japan, and by Bayer Yakuhin Ltd., Tokyo, Japan.

DOI: 10.1203/01.PDR.0000139426.16381.C8 therapy (IVIG), severe CAD sequelae such as CA dilation (5.05\% boys, $3.6 \%$ girls), CA aneurysm (3.15\% boys, $1.60 \%$ girls), CA narrowing $(0.11 \%$ both in boys and girls), and MI ( $0.05 \%$ boys, $0.07 \%$ girls) occur 1 mo after KD onset (1). The etiology of KD remains unknown, although hypercytokinemia and hyperchemokinemia occur during acute $\operatorname{KD}(2,3)$, and most KD symptoms can be explained by this pathophysiology. Vasoactive factors are also considered to be involved in KD and contribute to vascular remodeling, especially in patients who progress to CAD.

Many vasoactive factors, such as Ag II, endothelin (ET), and nitric oxide (NO), participate in vascular remodeling [review 
(4)]. RAS is thought to be involved in coronary thrombosis, vasoconstriction, and smooth muscle cell proliferation as well as in myocardial and coronary vascular cell remodeling. High plasma ACE levels increase arterial wall thickness (5). ACE activities also interfere with coronary vasomotion (6) and ventricular remodeling (7). Individuals carrying the $\mathrm{D}$ allele in $A C E \mathrm{I} / \mathrm{D}$ polymorphism have higher ACE activities in the blood $(8,9)$, and Cambien et al. (10) discovered that the D allele is a risk factor for MI. However, several subsequent studies of the $A C E$ I/D and $A T 1 R$ 1166A/C polymorphisms (11-14) have yielded conflicting results $(15,16)$. On the other hand, the results of a mega-clinical study $(17,18)$ have proven that ACE and AT1R antagonists have positive effects against cardiovascular events. How $A C E$ polymorphisms affect CAD remains controversial, but RAS is closely involved with CAD in adults.

Adult CAD and that caused by KD histologically differ. Adult CAD is mainly caused by atherosclerotic lesions, whereas the characteristic histologic feature of CAD caused by $\mathrm{KD}$ is severe intimal thickening $(19,20)$. In addition, AT1R activation, the main receptor of AgII, promotes proliferation, migration, hypertrophy, and the production of reactive oxygen species in vascular smooth muscle cells (VSMC) $(21,22)$. Thus, RAS should be closely associated with vascular remodeling in KD. Few studies have addressed renin/angiotensin in $\mathrm{KD}$. Takeuchi et al. (23) found that the $A C E \mathrm{I} / \mathrm{D}$ polymorphism genotype $\mathrm{I} / \mathrm{I}$ was a risk factor for CA aneurysm in a study of 36 patients with KD. Falcini et al. (24) reported that ACE activities are rather attenuated during the acute phase of KD. The present study investigates whether the $A C E \mathrm{I} / \mathrm{D}$ and $A T 1 R$ $1166 \mathrm{~A} / \mathrm{C}$ polymorphisms are associated with $\mathrm{CA}$ lesions in a relatively large cohort of patients with $\mathrm{KD}$ and examines $\mathrm{ACE}$ activities during the convalescent phase of $\mathrm{KD}$, when the $\mathrm{CA}$ is being remodeled.

\section{MATERIALS AND METHODS}

\section{Subjects}

We obtained written informed consent from the parents of 281 Japanese children with KD (176 boys and 105 girls, age $4.69 \pm 0.40$ y) to participate in this study, which conformed to the guidelines of the Nippon Medical School Ethics Committee. The patients were recruited from several Japanese medical centers. The patients included those recently diagnosed with KD between 1999 and $2003(n=183)$, and those who had been under clinical follow-up since $1984(n=98)$. Among them, 10 (included 2 ischemia patients) were from the Kinki area, 12 (included 1 ischemia patient) were from Kyushu, and the remainder were from the Kanto area of Japan. All the patients received aspirin, 276 received IVIG, and all those who had developed severe CA stenosis with myocardial ischemia received IVIG. Echocardiography screenings were performed at least twice a week within 1 mo of the onset of KD. When the CA became dilated to over 1.5-fold the size of the adjacent CA at $1 \mathrm{mo}$ after $\mathrm{KD}$ onset, coronary angiography was performed. Myocardial ischemia was diagnosed by treadmill exercise or dobutamine stress electrocardiography, and dobutamine stress ${ }^{99 \mathrm{~m}} \mathrm{Tc}$ tetrofosmin scintigraphy $(25,26)$. Severe CA stenosis with myocardial ischemia was defined as over $90 \%$ CA stenosis, and positive electrocardiographic or scintigraphic findings $(25,26)$. We compared data from two groups of KD patients: group $\mathrm{N}(n=246$, age $3.54 \pm 4.42 \mathrm{y})$, no myocardial ischemia; group I $(n=35$, age $10.97 \pm 1.12 \mathrm{y})$, severe CA stenosis with myocardial ischemia.

The controls consisted of 147 healthy adult volunteers (male, 69; female, 78; age $26.90 \pm 0.57$ y) from the Kanto area of Japan.

\section{Methods}

Genotyping by PCR. Genomic DNA was extracted from blood samples using a DNA blood mini kit (QIAGEN, Valencia, CA). We amplified DNA sequences that included the $A C E$ I/D and $A T 1 R 1166 \mathrm{~A} / \mathrm{C}$ polymorphisms using PCR. The $A C E$ I/D polymorphism was detected using the primers, 5'CCA GCC CTC CCA TGC CCA TAA C3' and 5'GAG AGA CTC AAG CAC GCC CCT CAC3', which were designed based on a reported nucleotide sequence (GenBank AC113554), and which correspond to positions 117033 and 117332, respectively. The PCR proceeded in an Applied Biosystems (Foster City, CA) 9700 PCR system using 10 ng DNA, 5 pM of each primer, $0.25 \mathrm{mM} \mathrm{dNTP}, 1.5 \mathrm{mM} \mathrm{MgCl} \mathrm{m}_{2}$, and $1.5 \mathrm{U}$ of $\mathrm{Taq}$ polymerase (Takara Bio Inc., Ohtsu, Japan) in a total volume of $25 \mu \mathrm{L}$. Amplification consisted of five PCR cycles of $94^{\circ} \mathrm{C}$ for $30 \mathrm{~s}, 72^{\circ} \mathrm{C}$ for $60 \mathrm{~s}$, and five cycles of $94^{\circ} \mathrm{C}$ for $30 \mathrm{~s}$ and $70^{\circ} \mathrm{C}$ for $60 \mathrm{~s}$ followed by 25 cycles of $94^{\circ} \mathrm{C}$ for $30 \mathrm{~s}$ and $68^{\circ} \mathrm{C}$ for $60 \mathrm{~s}$. The PCR products corresponding to the I and D alleles migrated at 610 and $323 \mathrm{bp}$, respectively on $1.5 \%$ agarose gels. To exclude mistyping of the D allele, independent PCR proceeded using insertion-specific primers, following the procedure of Lindpaintner et al. (13). The ATIR 1166A/C polymorphism was detected using the primers 5'GCA CAA TGC TTG TAG CCA AAG TCA C3' and 5'TCC GAG CAG CCG TCA TCT GTC TA3' according to the ATIR gene sequence (GenBank AF245699), which correspond to positions 49311 and 50182, respectively. The PCR reaction proceeded in the same manner as that for the $A C E$ I/D polymorphism. The PCR products were digested with the restriction enzyme DdeI overnight at $37^{\circ} \mathrm{C}$, and resolved by electrophoresis on $4 \%$ agarose gels into 605 and 289 bp bands for the A allele. When the C allele was present, the $289 \mathrm{bp}$ band was further digested into 146 and 143 bp bands.

ACE activity assay. Plasma samples were obtained from the KD patients before and after IVIG and during the convalescent phase ( 2 mo after KD onset), and control samples were immediately stored at $-80^{\circ} \mathrm{C}$.

ACE activities were measured according to the colorimetric procedure of Kasahara and Ashihara (27).

Statistics. We calculated odds ratios to estimate the relative risk of severe CA stenosis with myocardial ischemia in patients with the $A C E \mathrm{D}$ and $A T 1 R \mathrm{C}$ allele genotypes. The results were analyzed using logistic regression models and the software StatView 5.0 (SAS Institute Inc., Cary, NC). The calculated confidence interval (CI) was $95 \%$. Statistical significance was confirmed by the $\chi^{2}$ test, and when the predicted frequencies were below 10, Fisher's exact test confirmed the findings. A 
value of $p<0.05$ was considered significant. Statistical real numbers are expressed as means \pm SE. ACE activity was compared by one-way ANOVA. Significant differences were further analyzed using the posthoc test.

\section{RESULTS}

ACE I/D polymorphism. We obtained informative PCR results from 276 of the $281 \mathrm{KD}$ patients, and from 145 of the 147 controls. The frequency of the $A C E$ genotype was as follows: in controls: I/I, $45.5 \%(n=66)$; I/D, $46.2 \%(n=67)$; $\mathrm{D} / \mathrm{D}, 8.3 \%(n=12)$; in KD patients: I/I, $42.4 \%(n=117) ; \mathrm{I} / \mathrm{D}$, $45.6 \%(n=126) ; \mathrm{D} / \mathrm{D}, 12.0 \%(n=33)$ (Table 1$)$. The $A C E$ genotypes did not significantly differ between control and $\mathrm{KD}$ patients. We compared the $A C E$ genotype among KD patients: group $\mathrm{N}$ : I/I, $44.4 \%(n=107) ; \mathrm{I} / \mathrm{D}, 44.0 \%(n=106) ; \mathrm{D} / \mathrm{D}$, $11.6 \%(n=28)$; group I: I/I, $28.6 \%(n=10) ; \mathrm{I} / \mathrm{D}, 57.1 \%(n=$ $20)$; D/D, $14.3 \%(n=5)$ (Table 2). Significant differences among the genotypes between two groups were undetectable. However, when the genotype was analyzed with respect to the presence of the $\mathrm{D}$ allele between groups $\mathrm{N}$ and I, the frequency of the $\mathrm{D}$ allele (I/D $+\mathrm{D} / \mathrm{D})$ tended to be higher in group I ( $71.4 \%$ versus $55.6 \%, p=0.077$; odds ratio, $2.00 ; 95 \% \mathrm{CI}$, 0.92-4.34) (Table 2).

AT1R 1166A/C polymorphism. We obtained informative results from 273 of the $281 \mathrm{KD}$ patients, and from 138 of the 147 controls. Because the $\mathrm{C} / \mathrm{C}$ genotype polymorphism was found only once both in control and in $\mathrm{KD}$ patients, we analyzed the genotype with respect to the presence of the $\mathrm{C}$ allele. The frequency of this allele was as follows: in controls: $\mathrm{A} / \mathrm{A}, 85.5 \%(n=118) ; \mathrm{A} / \mathrm{C}+\mathrm{C} / \mathrm{C}, 14.5 \%(n=20)$; in $\mathrm{KD}$ patients: A/A, 83.5\% $(n=228) ; \mathrm{A} / \mathrm{C}+\mathrm{C} / \mathrm{C}, 16.5 \%(n=45)$ (Table 1). The genotypes did not significantly differ between controls and KD patients. Genotypes between the KD groups were Group N: A/A, 85.3\% $(n=203) ; \mathrm{A} / \mathrm{C}+\mathrm{C} / \mathrm{C}, 14.7 \%(n=$ 35); Group I: A/A, $71.4 \%(n=25) ; \mathrm{A} / \mathrm{C}+\mathrm{C} / \mathrm{C}, 28.6 \%(n=10)$ (Table 2). The frequency of the $\mathrm{C}$ allele $(\mathrm{A} / \mathrm{C}+\mathrm{C} / \mathrm{C})$ became significantly higher in group I than in group $\mathrm{N}(28.6 \%$ versus $14.7 \%, p=0.039$; odds ratio, 2.32; 95\% CI, 1.03-5.25) (Table 2).

Effect of D and C alleles of ACE I/D and AT1R 1166A/C polymorphisms, respectively. We examined whether patients with both a D and a C allele in the $A C E \mathrm{I} / \mathrm{D}$ and $A T I R 1166 \mathrm{~A} / \mathrm{C}$ polymorphisms, respectively, had an increased risk of developing severe CA stenosis with myocardial ischemia.

The number of patients with either or both of these alleles was considerably higher in group I than in group $\mathrm{N}$, compared

Table 1. Frequency of genotypes of $A C E I / D$ and $A T 1 R 1166 A / C$ polymorphisms in controls and KD patients

\begin{tabular}{ccc}
\hline Genotype & Control & \multicolumn{1}{c}{ KD } \\
\hline ACE & & \\
I/I & $45.5 \%(66)$ & $42.4 \%(117)$ \\
I/D & $46.2 \%(67)$ & $45.6 \%(126)$ \\
D/D & $8.3 \%(12)$ & $12.0 \%(33)$ \\
$\mathrm{AT} 1$ & & \\
$\mathrm{~A} / \mathrm{A}$ & $85.5 \%(118)$ & $83.5 \%(228)$ \\
$\mathrm{A} / \mathrm{C}+\mathrm{C} / \mathrm{C}$ & $14.5 \%(20)$ & $16.5 \%(45)$ \\
\hline
\end{tabular}

All results were NS.
Table 2. Frequency of genotypes of ACE I/D and ATIR 1166A/C polymorphisms among $K D$ patients

\begin{tabular}{cll}
\hline Genotype & Group N & \multicolumn{1}{c}{ Group I } \\
\hline $\mathrm{ACE}$ & & \\
$\mathrm{I} / \mathrm{I}$ & $44.4 \%(107)$ & $28.6 \%(10)$ \\
$\mathrm{I} / \mathrm{D}$ & $44.0 \%(106)$ & $57.1 \%(20)$ \\
$\mathrm{D} / \mathrm{D}$ & $11.6 \%(28)$ & $14.3 \%(5)$ \\
\hline$(\mathrm{I} / \mathrm{D}+\mathrm{D} / \mathrm{D})$ & $55.6 \%(134)$ & $71.4 \%(25) \boldsymbol{}$ \\
\hline $\mathrm{AT} 1 \mathrm{R}$ & & \\
$\mathrm{A} / \mathrm{A}$ & $85.3 \%(203)$ & $71.4 \%(25)$ \\
$\mathrm{A} / \mathrm{C}+\mathrm{C} / \mathrm{C}$ & $14.7 \%(35)$ & $28.6 \%(10)^{*}$ \\
\hline
\end{tabular}

All ACE Genotypes were NS.

I $p=0.077$; odds ratio, $2.00 ; 95 \%$ CI, $0.92-4.34$

$* p=0.039$; odds ratio, $2.32 ; 95 \% \mathrm{CI}, 1.03-5.25$.

with those who had neither allele $(61.6 \%$ versus $80.0 \%, p=$ 0.038; odds ratio, 2.71; 95\%CI, 1.05-6.99) (Table 3). That means both the $\mathrm{D}$ and $\mathrm{C}$ alleles are associated with the development of severe stenosis with ischemia in patients with KD. On the other hand, when we compared the number of patients with both of these alleles to those with neither or either one of these alleles, the risk of severe stenosis with ischemia tended to be higher in those who had both alleles (odds ratio, 2.71; $p=$ 0.061 ). That is, having both the $\mathrm{D}$ and $\mathrm{C}$ alleles increased the risk for severe stenosis with ischemia in KD. Although not statistically significant, the risk of developing severe stenosis with ischemia might be high in patients with both of these alleles.

Serum ACE activities during acute and convalescent phases of $K \boldsymbol{D}$. To evaluate how ACE activities change during the KD phase, we serially measured ACE activities in seven controls and in eight KD patients before and after IVIG and at the convalescent phase ( 2 mo after KD onset). Eight representative KD patients (four boys and four girls, age $2.5 \pm 0.6 \mathrm{y}$ ), whose clinical KD course was typical, were all good responders to IVIG and echocardiography did not show CA involvement. Their ACE I/D genotypes were I/I in two and I/D in six. The controls were two females and five males, age $25.6 \pm$ $0.8 \mathrm{y}$. Their ACE genotypes were I/I in two and I/D in five. The results were as follows: controls: $12.73 \pm 1.24$; KD pre-IVIG: $8.76 \pm 1.49$; KD post-IVIG: $13.46 \pm 1.11$; KD convalescent: $16.84 \pm 5.70 \mathrm{IU} / \mathrm{L}$. One-way ANOVA showed a significant difference between the groups $(p<0.01)$. The ACE activity of the KD convalescent phase was significantly increased compared with that of KD before and after IVIG $(p<0.001$ and $p$ $=0.039$, respectively) (Fig. 1).

Table 3. Effect of ACE I/D D and AT1R 1166A/C C alleles among KD patients

\begin{tabular}{ccc}
\hline & $\begin{array}{c}\text { Neither } \\
\text { (neither D allele } \\
\text { or C allele) }\end{array}$ & $\begin{array}{c}\text { Either or both } \\
\text { (D allele and/or } \\
\text { C allele) }\end{array}$ \\
\hline Group N & $38.4 \%(91)$ & $61.6 \%(146)$ \\
Group I & $20.0 \%(7)$ & $80.0 \%(28)^{*}$ \\
\hline
\end{tabular}

Odds ratio $(95 \% \mathrm{CI}), 2.71(1.05-6.99) ;\left(\chi^{2}\right.$ test $) ; p=0.038$ (Fisher's exact test). 


\section{Serial serum ACE activities in $\mathrm{KD}$ and controls}

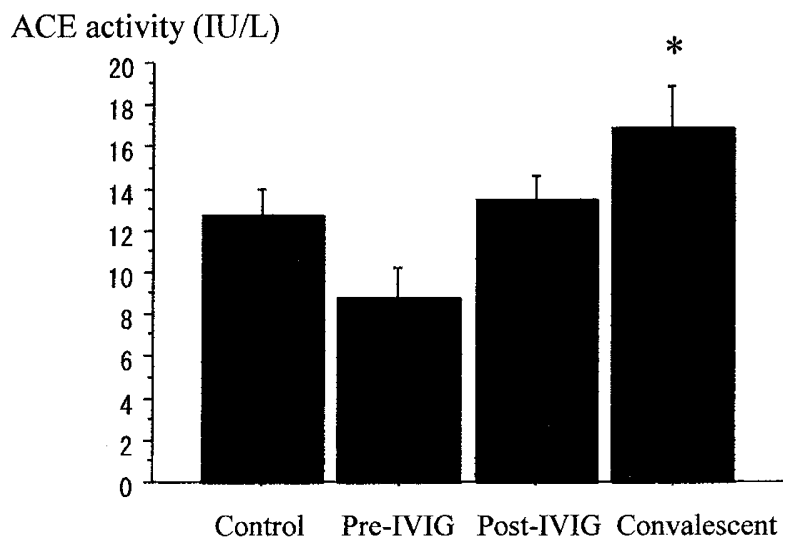

Figure 1. Serial serum ACE activities in KD and controls. ACE activities were serially measured in seven controls and in eight KD patients at pre-IVIG, post-IVIG and convalescent ( 2 mo after KD onset) phases. Control: $12.73 \pm$ 1.24; KD preIVIG: $8.76 \pm 1.49$; KD postIVIG: $13.46 \pm 1.11, \mathrm{KD}$ convalescent: $16.84 \pm 5.70 \mathrm{IU} / \mathrm{L}$. One-way ANOVA showed significant difference between the groups $(p<0.01)$. The ACE activity of KD convalescent phase was significantly increased compared with that of KD pre- and post-IVIG ( ${ }^{*} p$ $<0.001$ and $p=0.039$, respectively).

\section{DISCUSSION}

Since Cambien et al. (10) first suggested a relationship between $\mathrm{MI}$ and the $A C E \mathrm{I} / \mathrm{D}$ polymorphism, $A C E$ gene polymorphisms have been studied as a risk factor for CAD. Ribichini and colleagues (28) suggested that the D allele could be a risk factor for CA stent restenosis. Whereas the findings of other large clinical studies $(13,29)$ have confirmed a negative correlation between CAD and $A C E$ I/D polymorphism, Gardemann et al. (14) confirmed in a study of 2267 younger individuals that the $A C E \mathrm{D}$ allele increases the risk of CAD. Because the incidence of CAD is also affected by age and lifestyle, we supposed that the $A C E$ I/D polymorphism contributes more to effects in younger individuals. Renin/ angiotensin inhibition significantly attenuates unfavorable myocardial and vascular remodeling in rodents (30) but not in humans (29). Several factors can explain this disparity between rodents and humans, such as species differences and dose of renin/angiotensin antagonists. Moreover, there are basic histologic differences between adult CAD and CAD caused by KD. Atherosclerotic findings, such as macrophage foam cells, atheroma, and plaque formation, are mainly found in adult CAD. Thrombus formation followed by plaque rupture is thought to be one of the key causes of ischemic heart disease. On the other hand, $\mathrm{CAD}$ caused by $\mathrm{KD}$ is characterized by intimal thickening $(19,20)$ and myocardial ischemia because CA narrowing is mainly induced by intimal hyperplasia (26). AgII promotes vascular SMC proliferation and pro-inflammatory cytokine and growth factor production through AT1R activation $(21,22)$. These positive vascular remodeling effects of AgII should lead to intimal thickness. Thus, RAS probably contributes more to CAD that arises due to KD.

The present study found that the frequencies of the $A C E$ and $A T 1 R$ genotypes in controls and KD patients were similar to those reported for the normal Japanese population $(31,32)$. These facts suggest that the $A C E$ and $A T 1 R$ genotypes are not involved in the onset of KD.

Serum ACE activity during acute KD was significantly attenuated and recovered to even higher levels than controls during the convalescent phase. In addition, the $A C E \mathrm{I} / \mathrm{D}$ polymorphism D allele, which increases ACE activity $(8,9)$, was prevalent in KD patients with severe CA stenosis and ischemia. Our results imply that a higher renin/angiotensin state is closely associated with intimal hyperplasia and with the development of severe CA ischemia. On the other hand, the $\mathrm{C}$ allele of the $A T 1 R 1166 \mathrm{~A} / \mathrm{C}$ polymorphism is associated with aortic stiffness $(33,34)$, hypertension $(35,36)$, and CA vascular tone $(37,38)$. In addition, a combination of the $A C E \mathrm{D}$ and $A T 1 R \mathrm{C}$ alleles enhances the risk of $\operatorname{CAD}(15,16)$. Our results confirmed that having both of the $A C E \mathrm{D}$ and $A T 1 R \mathrm{C}$ alleles increases the risk of CA stenosis in children with $\mathrm{KD}$.

Harada et al. (39) proved that neointima is formed after aortic balloon injury in the AT1Ra knockout mouse. This means that signal transduction via the AT1Ra receptor is not always necessary for neointimal formation. However, they also confirmed that the amount of AT1R mRNA significantly increases after injury, and that an AT1R antagonist decreases neointima formation in the wild-type mouse. AgII signaling mediated by AT1R might not be essential for the development of neointimal formation, although AT1R-mediated signaling can modify neointimal formation and AgII is a useful means of blocking vascular remodeling. This also suggests that AgII blockades are useful for treating CA injury such as that associated with $\mathrm{KD}$. We probed the higher risk of myocardial ischemia in patients with KD carrying the $A C E \mathrm{D}$ and $A T 1 R \mathrm{C}$ alleles. We believe that patients with these polymorphisms should be carefully monitored and that AgII blockades should be considered for treating patients with KD.

Study limitations. We enrolled 147 controls and 281 patients with KD, the latter of which is a relatively small number for this type of study. The ischemia group consisted of 35 patients, which was also a small cohort. However, the prevalence of KD onset is only about 7000 per year in Japan, and KD patients who progress to ischemic heart disease account for $<0.1 \%$ of those with the disease. Although several centers participated in this study, collecting a sufficient number of patients with KD was difficult. In addition, we did not compare other CAD risk factors, such as serum cholesterol or serum inflammatory substances that are closely correlated to CAD in adults. Because the ischemia group was young $(10.97 \pm 1.12 \mathrm{y})$, we believe that CAD risk factors did not significantly affect this study.

Acknowledgments. The authors thank Mrs. Katsuko Honjo for excellent technical assistance.

\section{REFERENCES}

1. Yanagawa H, Nakamura Y, Yashiro M, Oki I, Hirata S, Zhang T, Kawasaki T 2001 Incidence survey of Kawasaki disease in 1997 and 1998 in Japan. Pediatrics 107:E33

2. Matsubara T, Furukawa S, Yabuta K 1990 Serum levels of tumor necrosis factor, interleukin 2 receptor, and interferon-gamma in Kawasaki disease involved coronaryartery lesions. Clin Immunol Immunopathol 56:29-36 
3. Gupta M, Noel GJ, Schaefer M, Friedman D, Bussel J, Johann-Liang R 2001 Cytokine modulation with immune gamma-globulin in peripheral blood of normal children and its implications in Kawasaki disease treatment. J Clin Immunol 21:193199

4. Intengan HD, Schiffrin EL 2001 Vascular remodeling in hypertension: roles of apoptosis, inflammation, and fibrosis. Hypertension 38:581-587

5. Bonithon-Kopp C, Ducimetiere P, Touboul PJ, Feve JM, Billaud E, Courbon D, Heraud V 1994 Plasma angiotensin-converting enzyme activity and carotid wall thickening. Circulation 89:952-954

6. Oike Y, Hata A, Ogata Y, Numata Y, Shido K, Kondo K 1995 Angiotensin converting enzyme as a genetic risk factor for coronary artery spasm. Implication in the pathogenesis of myocardial infarction. J Clin Invest 96:2975-2979

7. Myerson SG, Montgomery HE, Whittingham M, Jubb M, World MJ, Humphries SE, Pennell DJ 2001 left ventricular hypertrophy with exercise and ACE gene insertion/ deletion polymorphism: a randomized controlled trial with losartan. Circulation 103:226-230

8. Nakai K, Itoh C, Miura Y, Hotta K, Musha T, Itoh T, Miyakawa T, Iwasaki R, Hiramori K 1994 Deletion polymorphism of the angiotensin I-converting enzyme gene is associated with serum ACE concentration and increased risk for CAD in the Japanese. Circulation 90:2199-2202

9. Ferrari M, Mudra H, Grip L, Voudris V, Schachinger V, de Jaegere P, Rieber J, Hausmann D, Rothman M, Koschyk DH, Figulla HR, OPTICUS ACE Substudy 2002 Angiotensin-converting enzyme insertion/deletion polymorphism does not influence the restenosis rate after coronary stent implantation. Cardiology 97:29-36

10. Cambien F, Poirier O, Lecerf L, Evans A, Cambou JP, Arveiler D, Luc G, Bard JM, Bara L, Ricard S, Tiret L, Amouyel P, Alhenc-Gelas F, Soubrier F 1992 Deletion polymorphism in the gene for angiotensin-converting enzyme is a potent risk factor for myocardial infarction. Nature 359:641-644

11. Agerholm-Larsen B, Nordestgaard BG, Steffensen R, Sorensen TI, Jensen G, Tybjaerg-Hansen A 1997 ACE gene polymorphism: ischemic heart disease and longevity in 10,150 individuals. A case-referent and retrospective cohort study based on the Copenhagen City Heart Study. Circulation 95:2358-2367

12. Jeunemaitre X, Ledru F, Battaglia S, Guillanneuf MT, Courbon D, Dumont C, Darmon O, Guize L, Guermonprez JL, Diebold B, Ducimetiere P 1997 Genetic polymorphisms of the renin-angiotensin system and angiographic extent and severity of coronary artery disease: the CORGENE study. Hum Genet 99:66-73

13. Lindpaintner K, Pfeffer MA, Kreutz R, Stampfer MJ, Grodstein F, LaMotte F, Buring J, Hennekens CH 1995 A prospective evaluation of an angiotensin-convertingenzyme gene polymorphism and the risk of ischemic heart disease. N Engl J Med 332:706-711

14. Gardemann A, Fink M, Stricker J, Nguyen QD, Humme J, Katz N, Tillmanns H, Hehrlein FW, Rau M, Haberbosch W 1998 ACE I/D gene polymorphism: presence of the ACE D allele increases the risk of coronary artery disease in younger individuals. Atherosclerosis 139:153-159

15. Hamon M, Amant C, Bauters C, Richard F, Helbecque N, Passard F, McFadden EP, Lablanche JM, Bertrand ME, Amouyel P 1998 Dual determination of angiotensinconverting enzyme and angiotensin-II type 1 receptor genotypes as predictors of restenosis after coronary angioplasty. Am J Cardiol 81:79-81

16. Tiret L, Bonnardeaux A, Poirier O, Ricard S, Marques-Vidal P, Evans A, Arveiler D, Luc G, Kee F, Ducimetiere P, soubrier F, Cambien F 1994 Synergistic effects of angiotensin-converting enzyme and angiotensin-II type 1 receptor gene polymorphisms on risk of myocardial infarction. Lancet 344:910-913

17. Pfeffer MA, McMurray JJV, Velazquez EJ, Rouleau J-L, Kober L, Maggioni AP, Solomon SD, Swedberg K, Van de Werf F, White H, Leimberger JD, Henis M, Edwards S, Zelenkofske S, Sellers MA, Califf RM; Valsartan in Acute Myocardial Infarction Trial Investigators 2003 Valsartan, captopril, or both in myocardial infarction complicated by heart failure, left ventricular dysfunction, or both. N Engl J Med 349:1893-1906

18. Yusuf S, Sleight P, Pogue J, Bosch J, Davies R, Dagenais G 2000 Effects of an angiotensin-converting-enzyme inhibitor, ramipril, on cardiovascular events in highrisk patients. N Engl J Med 342:145-153

19. Amano S, Hazama F, Hamashima Y 1979 Pathology of Kawasaki disease: I. Pathology and morphogenesis of the vascular changes. Jpn Circ J 43:633-643

20. Suzuki A, Miyagawa-Tomita S, Nakazawa M, Yutani C 2000 Remodeling of coronary artery lesions due to Kawasaki disease: comparison of arteriographic and immunohistochemical findings. Jpn Heart J 41:245-256
21. Nickenig G, Harrison DG 2002 The AT(1)-type angiotensin receptor in oxidative stress and atherogenesis: part I: oxidative stress and atherogenesis. Circulation 105:393-396

22. Nickenig G, Harrison DG 2002 The AT(1)-type angiotensin receptor in oxidative stress and atherogenesis: part II: AT(1) receptor regulation. Circulation 105:530-536

23. Takeuchi K, Yamamoto K, Kataoka S, Kakihara T, Tanaka A, Sato S, Uchiyama M 1997 High incidence of angiotensin I converting enzyme genotype II in Kawasaki disease patients with coronary aneurysm. Eur J Pediatr 156:266-268

24. Falcini F, Generini S, Pignone A, Leoncini G, Cimaz R, Partsch G, Matucci-Cerinic M 1999 Are angiotensin converting enzyme and von Willebrand factor circulating levels useful surrogate parameters to monitor disease activity in Kawasaki disease? Endothelium 6:209-215

25. Kuramochi Y, Ohkubo T, Takechi N, Ogawa S 2001 Feasibility of percutaneous transluminal coronary angioplasty to patients with Kawasaki disease as an early management strategy. Pediatr Cardiol 22:183-187

26. Ogawa S, Fukazawa R, Ohkubo T, Zhang J, Takechi N, Kuramochi Y, Hino Y, Jimbo O, Katsube Y, Kamisago M, Genma Y, Yamamoto M 1997 Silent myocardial ischemia in Kawasaki disease: evaluation of percutaneous transluminal coronary angioplasty by dobutamine stress testing. Circulation 96:3384-3389

27. Kasahara Y, Ashihara Y 1981 Colorimetry of angiotensin-I converting enzyme activity in serum. Clin Chem 27:1922-1925

28. Ribichini F, Steffenino G, Dellavalle A, Matullo G, Colajanni E, Camilla T, Vado A, Benetton G, Uslenghi E, Piazza A 1998 Plasma activity and insertion/deletion polymorphism of angiotensin I-converting enzyme: a major risk factor and a marker of risk for coronary stent restenosis. Circulation 97:147-154

29. Koch W, Mehilli J, von Beckerath N, Bottiger C, Schomig A, Kastrati A 2003 Angiotensin I-converting enzyme (ACE) inhibitors and restenosis after coronary artery stenting in patients with the DD genotype of the ACE gene. J Am Coll Cardiol 41:1957-1961

30. Patten RD, Aronovitz MJ, Einstein M, Lambert M, Pandian NG, Mendelsohn ME, Konstam MA 2003 Effects of angiotensin II receptor blockade versus angiotensinconverting-enzyme inhibition on ventricular remodelling following myocardial infarction in the mouse. Clin Sci (Lond) 104:109-118

31. Kario K, Kanai N, Saito K, Nago N, Matsuo T, Shimada K 1996 Ischemic stroke and the gene for angiotensin-converting enzyme in Japanese hypertensives. Circulation 93:1630-1633

32. Takami S, Katsuya T, Rakugi H, Sato N, Nakata Y, Kamitani A, Miki T, Higaki J, Ogihara T 1998 Angiotensin II type 1 receptor gene polymorphism is associated with increase of left ventricular mass but not with hypertension. Am J Hypertens 11:316321

33. Lajemi M, Labat C, Gautier S, Lacolley P, Safar M, Asmar R, Cambien F, Benetos A 2001 Angiotensin II type 1 receptor-153A/G and $1166 \mathrm{~A} / \mathrm{C}$ gene polymorphisms and increase in aortic stiffness with age in hypertensive subjects. J Hypertens 19:407-413

34. Benetos A, Topouchian J, Ricard S, Gautier S, Bonnardeaux A, Asmar R, Poirier O, Soubrier F, Safar M, Cambien F 1995 Influence of angiotensin II type 1 receptor polymorphism on aortic stiffness in never-treated hypertensive patients. Hypertension 26:44-47

35. Wang WY, Zee RY, Morris BJ 1997 Association of angiotensin II type 1 receptor gene polymorphism with essential hypertension. Clin Genet 51:31-34

36. Bonnardeaux A, Davies E, Jeunemaitre X, Fery I, Charru A, Clauser E, Tiret L, Cambien F, Corvol P, Soubrier F 1994 Angiotensin II type 1 receptor gene polymorphisms in human essential hypertension. Hypertension 24:63-69

37. Amant C, Hamon M, Bauters C, Richard F, Helbecque N, McFadden EP, Escudero X, Lablanche JM, Amouyel P, Bertrand ME 1997 The angiotensin II type 1 receptor gene polymorphism is associated with coronary artery vasoconstriction. J Am Coll Cardiol 29:486-490

38. Prasad A, Narayanan S, Waclawiw MA, Epstein N, Quyyumi AA 2000 The insertion/ deletion polymorphism of the angiotensin-converting enzyme gene determines coronary vascular tone and nitric oxide activity. J Am Coll Cardiol 36:1579-1586

39. Harada K, Komuro I, Sugaya T, Murakami K, Yazaki Y 1999 Vascular injury causes neointimal formation in angiotensin II type 1a receptor knockout mice. Circ Res $84: 179-185$ 